\title{
The Role Internal Marketing in The Promotion of TECHNOLOGY USAGE AMONG TEACHERS: AN EMPIRICAL INVESTIGATION OF THE MEDIATING ROLE OF EXTRINSIC FACTORS LEADING TO IMPROVED TECHNOLOGY USE
}

\author{
Simmy Kurian, Hareesh N Ramanathan \& Berislav Andrlic
}
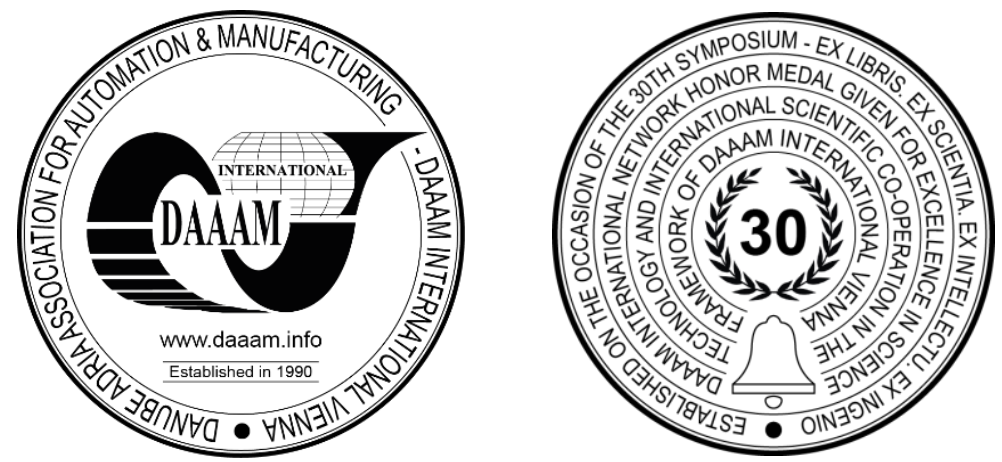

This Publication has to be referred as: Kurian, S[immy]; Ramanathan, H[areesh] \& Andrlic, B[erislav] (2019). The Role Internal Marketing in The Promotion of Technology Usage Among Teachers: An Empirical Investigation of the Mediating Role of Extrinsic Factors Leading to Improved Technology Use, Proceedings of the 30th DAAAM International Symposium, pp.0030-0037, B. Katalinic (Ed.), Published by DAAAM International, ISBN 978-3-90273422-8, ISSN 1726-9679, Vienna, Austria

DOI: $10.2507 / 30$ th.daaam.proceedings.004

\begin{abstract}
Technology adoption by the teaching community can be demonstrated by the relative ease of use and resultant use behaviour. Resource availability, as well as institutional support, are two extrinsic factors that are instrumental in framing a positive perception towards technology and ascertain the level of technology adoption by the teaching community.This paper aims to investigate the role of promotion of technology among teachers by examining the mediating role of extrinsic factors on technology usage among teachers. The study adopted a descriptive research design to collect data from a respondent base of 387 teachers from high schools and higher secondary schools, in India. It was found that there is an interactive mediation effect of, ease of use of technology in predicting the relation between resource availability and use behaviour. It was also found that resource availability had both, direct as well as the indirect effect on the use behaviour implying that resource availability wholly processed use behaviour of technology among teachers. Hence internal marketing campaigning focusing on the role of resource availability, institutional support and ease of use can enhance the usage of technology among teachers.
\end{abstract}

Keywords: Resource availability; institutional support; ease of use of technology; use behavior; Interactive mediation effect; Internal Marketing

\section{Introduction:}

Information and communication technology with its huge potential to give new dimensions to life on our planet, has transformed education too, in ways that have made it more student centric and focused. The role of teachers in the whole process has witnessed remarkable changes. The problem arises when the demands of this new role are not perceived correctly by the teacher who has the onus of leading the teaching learning paradigm by the technology means. Over a decade of research has now gone by in investigating the various barriers which restrict the use ICT tools by teachers in the classroom environment. 
Theoretical inadequacies as well as practical impediments have kept technology revolution still on the fences, of the established and running education system in schools. Several extrinsic and intrinsic factors have been quoted by literature as hindering the technology integration process. Factors like limited access to ICT resources, limited support from the institution, lack of sufficient training, lack of time and competency among teachers were some of the major factors which were reported as barriers[1] faced by teachers which led to their limited acceptance and use of technology. The main objective of this study is to ascertain how two major extrinsic factors, resource availability and institutional support affect the ease of use of technology among teachers and the subsequent use behavior of the technology tools.

\section{Problem Statement:}

Extrinsic factors that hamper the integration of ICT in education by teachers include challenges which are outside the control of the teachers themselves. Various barriers to ICT implementation have been reported as contributing to the predictive capability of technology integration as stated in the model developed by[2] Several research studies have revealed lack of sufficient resources as one of the prime factors affecting the smooth implementation of technology. According to[3] inaccessibility of ICT resources may not always be caused due to lack of sufficient hardware and software but may be the outcome of improper allocation of these resources, their poor quality or their inadequacy and inappropriateness. In a study conducted by[4] across 26 countries on the main barriers to ICT integration in schools, it was found that four out of the ten obstacles were related to poor resource availability. Some of these obstacles included inadequate number of computers, peripherals, software copies and poor internet access. Another major area of concern is the level of institutional support extended to the teachers to aid technology usage in the teaching learning process.[5] emphasized upon the fact that a lot of time wasted in fixing software and hardware problems which could be solved if the institution provided sufficient maintenance support.[3] argued that in the absence of such a support mechanism there would be greater risks of regular technical breakdowns which would discourage the use of these technology tools by the teachers.[6] argued that both novices as well as experienced teachers would equally be hit if the smooth delivery of a session gets affected by a technical breakdown. There is a need to investigate the extent to which these two barriers affect the ease of use of technology and the use of it by the teaching community.

\section{Literature Review and Hypothesis Formulation}

\subsection{Institutional support}

Several researchers have pointed out the wide gap between proposed and actual implementation of ICT integration into curriculum at the macro-level and its practical use in classrooms [7]. Many national level projects targeting ICT integration in schools failed to result in concrete changes in instructional practices at class level. In this respect, [8] pointed out that the irregularity in implementation between schools, suggests that the central policies and reforms do not inevitably lead to educational change in schools. Schools are considered to differ with respect to accomplishment levels, innovation capacity, and contextual characteristics which implied that educational improvement projects need to consider to a large extent the capacity of the institution.[9] Concluded that large-scale change could be effective, but required a degree of top-down initiative at the beginning, followed by larger attention paid to local [10] stated in their article that the analysis of school related policies such as ICT plan, ICT Support and ICT training have a significant effect on class use of ICT. The paper further emphasized that such ICT policies were much underutilized and discussed challenges in improving the potential of an ICT school policy. (Hayes, 2007)also recommended the need for a paradigm shift in core activities of schools including new teaching methods in order to achieve successful integration of ICT. The study was an attempt to better understand the influence of computer based technologies on learning opportunities in schools and the relative importance of local conditions on the teachers' attempts to integrate these technologies into the classroom environment. According to a report presented by (Becta, 2004) lack of concentration on ICT usage in training programmes was a barrier to teachers' use of ICT in the class room environment. Lack of training, led to anxiety towards the use of technology in some cases. Effective integration according to the UNESCO report largely depended on trained and supported teachers[11]. Therefore the greatest challenge of the schools was to provide ample support to teachers in acquiring appropriate technical skills needed for integrating computers in the classroom environment.

$\mathrm{H}_{1}$ : There is a significant relationship between Institutional support and ease of use of technology among teachers.

\subsection{Resource availability}

[12] argued that availability of ICT tools for effective instructional delivery were relatively low, except for laptops, multimedia projectors and internet facilities in tertiary institutions in Nigeria. The paper maintained that the lack of resources affected the quality of graduates produced from these institutions and recommended that ICT tools be provided in institutions of learning, teachers to make an effort to acquire these tools as they were an integral part of instruction delivery system and the government to introduce appropriate ICT policies and training programmes for teachers at all levels of education.[13] also suggested that governments invest in provision of ICT resources to schools for training because the findings of his research revealed that most ICTs available in schools were being utilized only for administrative purposes. 
[14] Surveyed teacher educators from five schools were randomly selected forming a sample size of 287 respondents, using the instrument tagged information and communication technology questionnaire (ICTRQ). The findings revealed that ICT resources were not available because of which, teachers were unable to access ICT for instructional development purposes. Based on these findings, it was recommended that the college authorities provide teacher educators in the institution with ICT resources and sponsor training and retraining programmes to produce ICT compliant products. A similar study on secondary schools in Ardokola and Jalingo Taraba state, with a sample of 264 respondents comprising of secondary school teachers and principals selected using stratified - random sampling technique reported very low availability of ICT resources and the extent of utilization of ICT resources in teaching and learning were equally very low [15]

According to [16], most ICT resources are not adequately available in schools. It implied that, even though teachers were adequately trained and willing to impart the knowledge they have to students, they were blocked from doing so by this lack of technological equipment and laboratory facilities. Research has suggestive evidence on the need for on - going inflow of funds for procurement and maintenance of ICT resources, ensuring existence of functional computer laboratories, consistent power supplies in schools and provision of in- house training for teachers all need to be ensured so that they keep in touch with the developments in ICT and related technologies.

H2: There is a significant relationship between Resource availability and ease of use of technology among teachers.

\subsection{Ease of use:}

It represents the degree to which teachers believe that using a particular system would be free from effort. The Impact project[17] and other studies identified a range of attributes which teachers felt would make educational technology easy to use. Some of these attributes included easy to learn, clear and understandable, easy to use, controllable, easy to remember. The study also listed a wide variety of skills and competencies needed to find ICT easy to use as reported by teachers themselves. Some of these are given in Table1 [18]

\begin{tabular}{|c|c|}
\hline Positive factors & Negative factors \\
\hline $\begin{array}{c}\text { regular use and experience of ICT outside the } \\
\text { classroom }\end{array}$ & difficulties in using software/hardware \\
\hline ownership of a computer & need more technical support \\
\hline confidence in using ICT & not enough time to use ICT \\
\hline easy to control the class & is too expensive to use regularly \\
\hline easy to think of new lesson ideas & insufficient access to the resources \\
\hline can get help and advice from colleagues & restricts the content of the lessons \\
\hline
\end{tabular}

Table 1. Positive and Negative Factors Influencing Perceived Ease of Use

[19] opined that if ICT was introduced and used by teachers in a manner that generated positive viewpoints regarding its perceived usefulness and perceived ease of use as a teaching and learning resource, it would assist encouraging positive attitudes towards ICT use as well as actual ICT use in classrooms.[20] found that for teachers to adopt or use ICT, teachers need to see the necessity of making such changes and how that would affect their practice and students learning. Another study stated the mediation effect of ICT teacher competency and ease of use of technology[21]. This technology adoption by teachers would reflect in their perception of ease of use of ICT tools and their actual use behavior.[18] stated that when teachers had confidence in using ICT, perceived it to be useful for their personal work and for their teaching they were likely to prolong their use even in the future. [22] while investigating factors affecting users perception over adoption of technology found that communication channels played a critical role in determining usefulness perceptions towards IT adoption. Also influential in this regard was the quality of relationship between managers and peers as well as the selfefficacy of the users in deciding the perceived ease of use.

H3: There is a significant relationship between Ease of Use and ICT use behaviour among teachers.

H4: There is a significant relationship between Resource Availability and ICT use behaviour among teachers.

\subsection{Use behavior}

[23]stated that, while teacher use of ICT for report writing, communication, planning and creating resources showed an overall increase, likewise did the integration of ICT into daily teaching and learning increase. The findings clearly indicated an increase in pedagogical and professional use of ICT. This increase was attributed to the presence of strong and reliable network and other ICT resources which were now more readily available than before and robustness of the upgraded systems.[24] elaborated on users' beliefs and attitudes changing over a period of time and impacting their 
IT usage .Several other literatures have also confirmed that experience with the use of technology had an influence on intention to use and actual use of information technology[25] ; [26] indicated that there are differences in technology integration and technology uses based on the grades where the implementation was taking place in the school. Teachers at the various grade levels differed in how technology was integrated and used in their classrooms. Research indicated that professional development opportunities were important to bring teachers together to discuss and share ideas for integrating technology and also showed that teachers needed to learn to integrate technology within the context of their classroom through practice, reflection, and sharing of teaching practices.

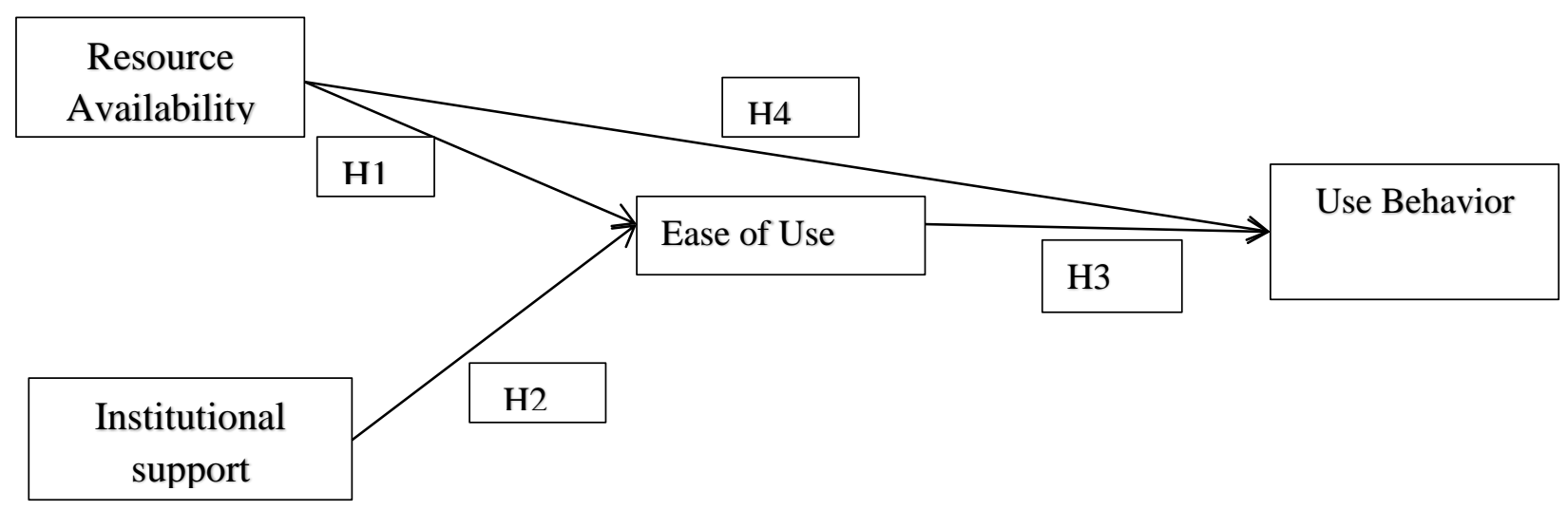

Fig. 1. Hypothetical Model

\section{Methods Used:}

A survey method to test the proposed model was adopted and to undertake the survey an instrument was prepared using constructs from existing empirical studies which were identified after a detailed review of literature. The constructs relating to resource availability and institutional support were adapted from UTAUT framework and ease of use and use behavior construct were adapted from the TAM framework. These constructs were modified to suit the study after a pilot study was conducted on 150 samples. The primary data was collected from teachers of high schools and higher secondary schools across 14 districts in the state of Kerala, India. Proportionate random sampling technique was utilized to select the respondents. A total of 387 samples were considered for the study.

\section{Results}

The data so collected was analyzed using the structural equation modeling. A two-step approach was followed to estimate the measurement model with respect to convergent and discriminant validities and followed by testing the structural model framework and research hypotheses. A path analysis attempted at various stages of the analysis checked the association between resource availability as well as institutional support with other constructs namely ease of use and use behavior. [27] a commonly used criterion, was adopted to quantify the degree of shared variants between the latent variables of the model.

By measuring average variance extracted (AVE) and composite reliability (CR), the convergent validity of the measurement model can be projected. The values above 0.5 are accepted for AVE and 0.7 for CR. The values reported for all the variables under study were found to be satisfactory. Path analysis was employed to analyse the statistics through AMOS 22.0 software. Hair, (2006) proposed a two- step approach for analyzing the data. In tune with this proposal, this research also adopted this two-step approach. Through path analysis, various measures of statistics were employed to assess the fit of data with the proposed model.

\begin{tabular}{|l|c|c|c|}
\hline \multicolumn{1}{|c|}{ Variable } & CR & AVE & $\begin{array}{c}\text { Cronbach } \\
\text { alpha }\end{array}$ \\
\hline Resource availability & 0.844 & 0.643 & 0.83 \\
\hline Institutional Support & 0.777 & 0.638 & 0.813 \\
\hline Ease Of Use & 0.729 & 0.871 & 0.927 \\
\hline Use Behaviour & 0.9 & 0.602 & 0.88 \\
\hline
\end{tabular}

Table 2. Constructs with their Composite Reliability, Average Variance Extracted \& Cronbach Alpha 
The ratio of chi square minimum to the degree of freedom (CMIN/DF) was 1.191, which falls in the ideal fit criteria[28]. The value indicates an ideal fit between the data and the model. Other indices like GFI (goodness-of-fit index), CFI (comparative fit index), should be greater than 0.9, and RMSEA (root mean square error of approximation) should be less than 0.024 (Hair, 2006). The values of these indices reflect that the model fits the data (CMIN/DF $=1.191, \mathrm{GFI}=0.998$, $\mathrm{CFI}=0.999$, RMSEA $=0.024)($ Refer Table 3$)$. Hence it can be observed that the conjectured model illustrating the relationship between the variables mentioned in the hypothesis was found to be fit for further analysis.

\begin{tabular}{|l|l|c|}
\hline Measures & Threshold Values & $\begin{array}{c}\text { Observed } \\
\text { Values }\end{array}$ \\
\hline CMIN/DF & $\begin{array}{l}<3 \text { Ideal. The values are acceptable } \\
\text { between 3 and 5 (Hair et al. 2010)[29] }\end{array}$ & 1.191 \\
\hline CFI & $\begin{array}{l}>0.95 \text { (D, Coughlan J, \& Mullen M, } \\
\text { 2008)[30] }\end{array}$ & .999 \\
\hline GFI & $>0.95$ (Baumgartner, 1996)[31] & .998 \\
\hline AGFI & $>0.80$ (Baumgartner, 1996) & .983 \\
\hline RMSEA & $\begin{array}{l}<0.05 \text { good and 0.05 to 0.10 Moderate (D, } \\
\text { Coughlan J, \& Mullen M, 2008)[32] }\end{array}$ & .024 \\
\hline P CLOSE & $>0.05$ & .455 \\
\hline
\end{tabular}

Table 3. Model Fit Statistics.

The details about the path coefficients are listed in Table 3. The relationship of resource availability and institutional support to ease of use and use behavior were found to be significant hence the hypothesis was accepted ( $\mathrm{p}<0.05)$. The path analysis at various stages checked the association of resource availability with other constructs namely ease of use as well as use behavior. The study acknowledged that resource availability was both directly related to both ease of use and use behavior. The relationship between these two variables was checked and found to be positively related. Ease of use at the same time was found to mediate the effect of resource availability on use behaviour

\begin{tabular}{|c|c|c|c|c|c|c|c|}
\hline IV & DV & $\begin{array}{c}\text { Regression } \\
\text { coefficient }\end{array}$ & $\begin{array}{c}\text { Standardise } \\
\text { d R.C }\end{array}$ & C.R. & P value & Decision & Type \\
\hline $\begin{array}{c}\text { Resource } \\
\text { Availability }\end{array}$ & Ease of use & .705 & .522 & 9.601 & $<0.05$ & $\begin{array}{c}\text { Accepte } \\
\text { d }\end{array}$ & Hypothesized \\
\hline $\begin{array}{c}\text { Institutional } \\
\text { support }\end{array}$ & Ease of use & .000 & .004 & .000 & $<0.05$ & $\begin{array}{c}\text { Accepte } \\
\text { d }\end{array}$ & Hypothesized \\
\hline Ease of use & Use Behavior & .198 & .143 & 2.767 & $<0.05$ & $\begin{array}{c}\text { Accepte } \\
\text { d }\end{array}$ & Hypothesized \\
\hline $\begin{array}{c}\text { Resource } \\
\text { Availability }\end{array}$ & Use Behavior & .926 & .495 & 9.597 & $<0.05$ & $\begin{array}{c}\text { Accepte } \\
\text { d }\end{array}$ & Hypothesized \\
\hline
\end{tabular}

Table 4. Regression Coefficients

\section{Testing of Direct, Indirect and Mediating Effects of Resource Availability}

Since its introduction into sociology, path analysis has been used to decompose the influences of one variable on another into total, direct, and indirect effects. Path analysis distinguishes three types of effects: Direct effects: association of one variable with another net of the indirect paths specified in the model Indirect effects: association of one variable with another mediated through other variables in the model computed as the product of paths linking variables Total effect: direct effect plus indirect effect(s) [33]. Hypotheses involving mediation are common in the behavioral sciences. Mediation exists when a predictor affects a dependent variable indirectly through at least one intervening variable, or mediator [34] 


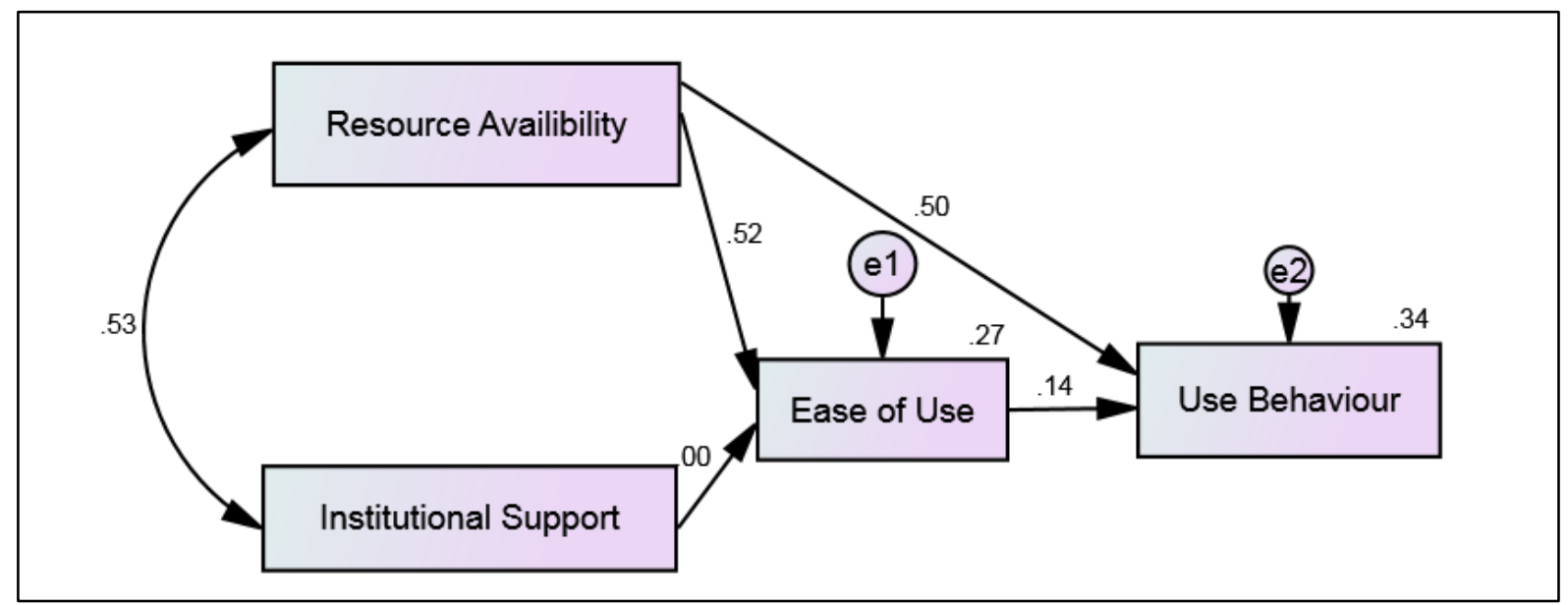

Fig. 2. Path Diagram

Here in the hypothesized model, there is a direct as well as indirect effect between resource availability and use behavior. It is hypothesized that the relationship between resource availability and use behavior is mediated by ease of use. This hypothesis is tested by examining the direct, Indirect and the total effect.

\section{7a. Standardized Direct Effects}

\begin{tabular}{|c|c|c|c|}
\hline & Institutional Support & Resource availability & Ease of Use \\
\hline Ease of Use & .000 & .522 & .000 \\
\hline Use Behaviour & .000 & .495 & .143 \\
\hline
\end{tabular}

Table 4. Standardized Direct Effects

The standardized direct (unmediated) effect of Resource availability on Use Behaviour is .495. That is, due to the direct (unmediated) effect of Resource availability on Use Behaviour, when Resource availability goes up by 1 standard deviation, Use Behaviour goes up by 0.495 standard deviations. This is in addition to any indirect (mediated) effect that Resource availability may have on Use Behaviour.

\section{7b. Standardized Indirect Effects}

\begin{tabular}{|c|c|c|c|}
\hline & Institutional Support & Resource availability & Ease of Use \\
\hline Ease of Use & .000 & .000 & .000 \\
\hline Use Behavior & .000 & .075 & .000 \\
\hline
\end{tabular}

Table 6. Standardized Indirect Effects

The standardized indirect (mediated) effect of Resource availability on Use Behavior is .075. That is, due to the indirect (mediated) effect of Resource availability on Use Behaviour, when Resource availability goes up by 1 standard deviation, Use Behaviour goes up by 0.075 standard deviations. This is in addition to any direct (unmediated) effect that Resource availability may have on Use Behaviour.

\section{7c. Mediation Effect:}

Since the direct and indirect effects were found to be significant, this can be considered as partial mediation. Partial mediation maintains that the mediating variable accounts for some, but not all, of the relationship between the independent variable and dependent variable. Partial mediation implies that there is not only a significant relationship between the mediator and the dependent variable, but also some direct relationship between the independent and dependent variable [35].

\section{Conclusion}

This study concentrated on finding the influence of resource availability and institutional support on ease of use and thereby the subsequent impact on use behaviour of ICT among teachers. It was found that a strong institutional support did have a positive and significant influence on the ease of use of technology. Implying that institutions which provide 
for better support in terms of infrastructure, training and communication of outcomes pertaining to ICT implementation in schools would achieve among greater ease of use of technology among their teachers. As suggested by earlier research from the 1990s, there is increasing emphasis on the perspective of school leadership being instrumental in integrating technology to the educational paradigm [36]. The need for transformational leadership that focuses on building organizational capacity and innovation, and adopting a commitment-building strategy for school restructuring [36] all of these findings remain congruent with the result of this study. [37] pointed out that barriers to adoption of any technology by human factors included lack of standardized instructions for use of the technology, lack of training, lack of adequate equipment, the fear of errors and repercussions, and dealing with technical issues .Hence by providing the right proportion of resources would enable the users to improve their ease of use of it. On a similar note [38] emphasized the importance of the human factor in the successful acceptance and said that lack of training could also hamper the process.

The major finding from the study was the influence of resource availability which had both a direct and indirect impact on the ease of use as well as use behaviour of technology among teachers. Ease of use of technology was found to have a mediating role between teacher's use of technology and the availability of resources, implying that ICT resources needed to be readily available and easily accessible to ensure that ICT be perceived to be easy to use by the teachers. This in turn would result in greater use of technology by teachers in various teaching learning processes in schools. Among the most talked about extrinsic barriers are the lack of ICT resources, lack of support and time [1] and findings from the current study prove the same point that given adequate resources both ease of use of technology as well as use of technology behaviour among teachers would considerably improve. Hence the institution must take active efforts to ensure availability and easy access of ICT resources to facilitate the smooth integration of technology into the educational processes. The findings of the study substantiate the existing knowledge on the importance of teachers' attitude towards technology use and acceptance. In order to make effective use of technological innovation in education the teacher must be first and foremost convinced of his or her ability to embrace the innovation. Hence the study clarifies the importance of both institutional support as well as resource availability as two important extrinsic ingredients to making teachers' perception positively inclined towards technology use.

\section{References:}

[1] Simin Ghavifekr, T. K. (2008). Teaching and Learning with ICT Tools: Issues and Challenges from Teachers Perceptions . Malaysian Online Journal of Educational Technology Volume 4, Issue 2, 38-57.

[2] Kurian,S., Ramanathan H.N.,(2018) Gauging the Importance of Institutional Vision Factors in Predicting Teacher Technology Competence using Multi-Layer Perceptron , 4th International Management Conference on "Advances in Management through Research, Innovation \& Technology"

[3] Becta. (2004). What the research says about using ICT in Geography. Coventry: Becta.

[4] Pelgrum, W. J. (2001). Obstacles to the integration of ICT in education: results from a worldwide educational assessment. Computers \& Education, 37, 163-178.

[5] Korte, W. B. (2007). Benchmarking access and use of ICT in European schools 2006: Results from Head Teacher and A Classroom Teacher Surveys in 27 European countries. . eLearning Papers, 2(1), 1-6.

[6] Sicilia, C. (2005). The Challenges and Benefits to Teachers' Practices in Constructivist Learning Environments Supported by Technology. . Montreal.: Unpublished master's thesis, McGill University.

[7] Jo Tondeur, J. v. (2007). Curricula and the use of ICT in education:. British Journal of Educational Technology Vol 38 No $6,962-976$.

[8] Visscher, A. J., \& Coe, R. (2003). School performance feedback systems: Conceptualisation, analysis, and reflection. School Effectiveness and School Improvement, 321-349

[9] Fullan, M. (2001). The new meaning of educational change . (3rd ed.). London: RoutledgeFalmer.

[10] Jo Tondeur, Hilde van Keer, Johan van Braak, \& Mar. ( 2008). ICT integration in the classroom: Challenging the potential of a school policy. Computers \& Education volume 51, Issue 1, August, Pages 212-223.

[11] UNESCO. (2003). Meeting on Documenting Experiences in the use of ICT in Education and Schoolnet Operations. Bangkok: UNESCO.

[12] Egomo, J.E, Enyi, B.I, \& Tah, M.M. (2012). Availability and utilization of ICT tools for effective instructional delivery in tertiary institutions in cross river state, Nigeria. Global advanced research journal of educational research and review. 1(8), 190-195.

[13] Adedeji, T. (2011). Availability and use of ICT in south - western Nigeria colleges of education.. International Multidisciplinary journal,5(5),, 315- 331.

[14] Jude, W. I., \& Joyce Terumbur Dankaro. (2012). ICT Resource Utilization, Availability and Accessibility by Teacher Educators for Instructional Development in College of Education katsina-Ala. New Media and Mass Communication ,IISTE.

[15] Austine.A, \& Amuchie. (2015). Availability and Utilization of ICT Resources in Teaching and Learning in Secondary Schools in Ardo-Kola and Jalingo, Taraba State. Journal of Poverty, Investment and Development,IISTE, Vol.8.

[16] Ngwu, O. (2014). Assessment of availability and utilization of ICT resources in teaching in F.C.E Eha-Amufu Enugu Nigeria. ICELW 2014. 
[17] Watson, D. (1993). The Impact report:An evaluation of the impact of Information technology on children;s achievements in primary and secondary schools. London.

[18] Cox, M., Preston, C., \& Cox, K. (1999). What Factors Support or Prevent Teachers from Using ICT in their Classrooms? Paper presented at the British EducationalResearch Association Annual Conference. University of Sussex, Brighton.

[19] Papastergiou, M. ( 2009). Digital game-based learning in high school computer science education: Impact on educational effectiveness and student motivation . Computers and Education, 52(1):1-12.

[20] Davis., F. D., Bagozzi, R. P., \& Warshaw, P. R. (1989). User acceptance of computer technology: A comparison of two theoretical models Management Science,. Management Science, 35(8): 982-10003.

[21] Kurian, Simmy,Toc Ramanathan, N. Hareesh,Toc \& Andrlic, Berislav(2018). Marketing Perception of Educators on the Mediation Role of Ease of Use in Predicting the Relationship between Teacher Competence and Use Behaviour. International Journal - VALLIS AUREA • Volume 4• Number 2 Croatia, December 2018,UDK 37.091.33-028.26:339.138(540); DOI 10.2507/IJVA.4.2.1.51.

[22] Monzav, T., Behrouz Zare, \& Amir Hossein Ghapanch. (2013). Investigating the Impact of External Factors on User Perceptions: A Case Study of Software Adoption in Middle East. The International Technology Management Review, Vol. 3 , No. 3, 160-174.

[23] Ward, D. L., Bronwyn Weston , \& Tracy Bowker. (2007). School ICT Network Infrastructure Upgrade Project: Evaluation of Early Impacts. Report prepared for the Ministry of Education: Cognition Consulting.

[24] Bhattacherjee, A., \& Premkumar ,G. (2004). Understanding Changes in Belief and Attitude Toward Information Technology Usage: A Theoretical Model and Longitudinal Test. Management Information Systems Quarterly, Vol. 28, Iss. 2.

[25] Thompson, R., Compeau, D., \& Higgins, C. (2006). Intentions to use information technologies: An integrative model. Journal of Organizational and End User Computing, 18(3), 25-46.

[26] Gorder, L. M. ( 2008). A Study of Teacher Perceptions of Instructional Technology Integration in the Classroom. The Delta Pi Epsilon Journa, Volume L, No. 2, Spring/Summer.

[27] Fornell, C. a. (1981). Evaluating Structural Equation Models with Unobservable Variables and Measurement Error. Journal of Marketing Research (18:1), , pp. 39-50.

[28] Hair, J. B. (2006). Multivariate Data Analysis. 6th Edition. Upper Saddle River: Pearson Prentice Hall.

[29] Hair, J., Black, W., Babin, B., et al. (2010). Multivariate data analysis. Prentice Hall.

[30] D, H., Coughlan J, \& Mullen M. (2008). Structural Equation Modeling: Guidelines for Determining Model Fit. Journal of Business Research Methods, 53-60.

[31] Baumgartner, H. \&. (1996). Applications of structural equation modeling in marketing and consumer research: A review. . International Journal of Research in Marketing, 13, 139-161.

[32] Bollen, K. (1989). Structural Equations with Latent Variables. New York.: John Wiley and Sons, Inc.

[33] Kristopher J. Preacher, A. F. (2008). Asymptotic and resampling strategies for assessing and comparing indirect effects in multiple mediator models. Behavior Research Methods, 40 (3), 879-891.

[34] Baron, R. M. (1986). The moderator-mediator variable distinction in social psychological research: Conceptual, strategic, and statistical considerations. Journal of Personality and Social Psychology, 51(6), , 1173-1182.

[35] Hallinger, P. a. (1998). Exploring the principal's contribution to school effectiveness: 1980-1995 . School Effectiveness and School Improvement, 9(2), 157-179.

[36] Leithwood, K. (1994). Leadership for school restructuring. . Educational Administration Quarterly, 30(4), , $498-518$.

[37] Mikulic, I[va] \& Stefanic, A[nja] (2018). The Adoption of Modern Technology Specific to Industry 4.0 by Human Factor, Proceedings of the 29th DAAAM International Symposium, pp.0941-0946, B. Katalinic (Ed.), Published by DAAAM International, ISBN 978-3-902734-20-4, ISSN 1726-9679, Vienna, Austria DOI: 10.2507/29th.daaam.proceedings.135.

[38] Stojkić, Ž.; Veža, I. \& Bošnjak, I. (2015). A concept of information system implementation (crmand erp) within industry 4.0, Annals of DAAAM and Proceedings of the International DAAAM Symposium, pp. 912-919. 